\title{
セルレニン耐性による酶酸低生産性清酒酵母の分離
}

\author{
後藤 (山本) 奈美・劉 宏芳*・石川雄章・岡崎直人 \\ (*現在：中国, 合爾濱瑞赤新技術開發公司, 国税庁醸造研究所)
}

平成 12 年 1 月 19 日受理

\section{Low Acetic Acid-Producing Strains Isolated from Cerulenin-Resistant Mutants of Sake Yeast}

\author{
Nami Goto-Yamamoto, Liu Hong-Fang, Takeaki Ishikawa and Naoto OKazAKI \\ (National Research Institute of Brewing, 3-7-1, Kagamiyama, Higashi-Hiroshima, 739-0046)
}

Low acetic acid-producing strains were isolated from cerulenin-resistant mutants of the sake yeast K 7 (Saccharomyces cerevisiae). Acetic acid is considered to be an intermediate metabolite of the cytosolic acetyl CoA synthetic pathway from acetaldehyde. Cytosolic acetyl CoA is used for the biosynthesis of sterols, fatty acids, etc. Cerulenin is an inhibitor of fatty acid synthase. Thus, a mutant producing lower levels of acetic acid and higher levels of acetyl CoA is supposed to show cerulenin resistance. Out of 80 cerulenin-resistant mutants, four were selected as low acetic acid-producing mutants using a fermentation test with a liquid synthetic medium and a small scale sake fermentation test. K 7 and one mutant, K $7-163$, produced $136.6 \mathrm{mg} / \ell$ and $16.4 \mathrm{mg} / \ell$ of acetic acid, respectively, in pilot scale sake making. Three of the four mutants showed higher acetyl CoA synthetase (ACS) activity than $\mathrm{K} 7$ during the late period of growth, which appeared to be the reason for their low acetic acid productivity. However, all four mutants showed multi-drug resistance, and/or high ethyl caproate productivity, which was probably caused by FAS 2 mutation. Thus, further studies are needed to confirm the relationship between low acetic acid productivity and cerulenin resistance.

Key words : 酢酸・清酒酵母・セルレニン耐性

\section{緒}

\section{言}

清酒をはじめとする酒類では，酢酸は酸臭の原因と なるため, 高濃度にならないよう, 注意が必要な成分 とされている。清酒醸造では, 乳酸菌活染のない場合 でも，過剩な通気によって酢酸の生成が上昇すること が報告されており ${ }^{1)}$, 小仕込みを行うと酢酸濃度が高 くなるのはこのためと考えられる゙2。またワイン醸造 では, 原料糖濃度が高いほど酢酸の生成が多いほか, 酵母菌株の違いや $\mathrm{pH}$ の影響を受けることが知られて いる ${ }^{3,4)}$ 。

清酒酵母は, 長い間に酢酸生成の少ない株が選択さ れていると考えられるが, 酢酸の過剰な生成を避ける
には, 通気や糖濃度に, ある程度の注意が必要である。 そこで, 突然変異によって, 比較的高糖濃度条件でも 酢酸低生産性を示すような酵母の育種を試みた。

発酵条件において，酢酸はアセトアルデヒドから細 胞質のアルデヒドデヒドロゲナーゼ（ALD）によって 生成され, 生成した酢酸はアセチル Co-A シンセター ゼ（ACS）によってアセチル $\mathrm{Co}^{-} \mathrm{A}$ 合成の基質として 消費される。実験室酵母では, ACS 活性が高く, ALD 活性の低い株は酶酸の生成が低いことが報告されてお $\eta^{5)}$, 発酵条件での酵母による酢酸の生成は, 細胞質に おけるアセチル Co-A 合成系の代謝中間体として生 成した酢酸がリークしたものと考えられる。

細胞質のアセチル $\mathrm{Co}^{-} \mathrm{A}$ は, ステロールや脂肪酸等 
の生合成に使用される。従って, 脂肪酸合成酵素の阻 害剤であるセルレニン耐性株の中には，酶酸からアセ

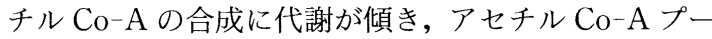
ルが大きいため，セルレニンで脂肪酸合成酵素の大部 分が阻害された条件でも，ある程度脂肪酸が合成され て生育可能であり，酢酸の生成が少ない株があるので はないかと考えた。そこで, 協会 7 号酵母のセルレニ ン耐性株からの酢酸低生産性変異株の分離を行ったの で，報告する。

\section{実 験 方 法}

\section{1. セルレニン耐性株の分離}

協会 7 号酵母を $0.1 \mathrm{M}$ リン酸バッファー $(\mathrm{pH} 8.0)$ に懸濁し，5\%（v/v）のエチルメタンスルフォネイト （EMS）を添加して $30^{\circ} \mathrm{C} ， 60$ 分間静置した。その後, $5 \%$ チオ硫酸ナトリウム溶液に懸濁して反応を停止し, 滅菌水で洗浄後, 1 または $5 \mathrm{mg} / \ell$ のセルレニンを含 む YEPG（1\%酵母エキス, $1 \%$ ポリペプトン, $4 \%$ グリ セロール）寒天培地に塗抹した。 $30^{\circ} \mathrm{C} て ゙$ 培養後, 生育 したコロニーを同濃度のセルレニン含有 $\mathrm{YEPG} フ ゚$ プ 一トに画線し，単コロニーを分離した。ここで，グリ セロールを炭素源としたのは, 多剤耐性を示す呼吸欠 損株の分離を避けるためである。

\section{2. 酶酸低生産性変異株の選択}

液体発酵試験には，Wickerham の合成培地(Difco) を基本とし，窒素源をイネのグルテリンの主要アミノ 酸である $850 \mathrm{mg} / \ell$ アルギニン, $994 \mathrm{mg} / \ell$ グルタミ ン, $370 \mathrm{mg} / \ell$ グリシン, $650 \mathrm{mg} / \ell$ ロイシン, $518 \mathrm{mg} /$ $\ell$ セリン, $579 \mathrm{mg} / \ell$ バリンの混合物, 炭素源を $10 \%$ グ ルコースとし, 乳酸で $\mathrm{pH} 4.0$ に調整した合成培地(以 下，合成培地）を用いた。この合成培地にプレートで 培養した菌体を懸濁し， $15^{\circ} \mathrm{Cで} 7$ 日間静置培養した後, $\mathrm{OD}_{660}$ 及び酶酸濃度を測定した。

3. 小仕込み試験及びパイロットスケールの清酒䁔 造試験

小仕込みは，凍結麭と $\alpha$-米を用い, Table 1 に示す 仕込み配合で行った。酵母はBé 6.4 の䴯エキスで, $25^{\circ} \mathrm{C}$ で 1 日振とう培養後, 1 日静置培養し, 集菌・洗浄 後, $2 \times 10^{7} \mathrm{cells} / \mathrm{m} \ell$ になるように添えの仕込み水に添 加した。留め後は 1 日 $1^{\circ} \mathrm{C}$ 昇温し, $15^{\circ} \mathrm{C} て ゙ 一$ 定とし, 協 会 7 号の 1 日当たりの炭酸ガス減量が $2 \mathrm{~g}$ よりも小さ くなった 22 日目に遠心分離で上槽した。対照として,
Table 1 Proportion of raw materials used in small scale sake making.

\begin{tabular}{lcccc}
\hline \hline & 1 st & 2 nd & 3 rd & Total \\
\hline$\alpha$-rice (g) & 50 & 85 & 185 & 320 \\
Frozen koji (g) & 25 & 31.25 & 43.75 & 100 \\
Water (m $)$ & 118 & 185.5 & 345.5 & 650 \\
Lactic acid (m $\ell)$ & 0.35 & & & 0.35 \\
\hline Temperature $\left({ }^{\circ} \mathrm{C}\right)$ & 15 & 13 & 12 & \\
\hline
\end{tabular}

協会 7 号，及び酢酸生成の低いNo. 86 を用いた。

パイロットスケールの清酒醸造は, 精米歩合 $70 \%$ の 日本晴を用い，総米 $100 \mathrm{~kg}$ ，速醸酒母を用い，通常の 仕込み方法で行った。留めは約 $10^{\circ} \mathrm{C} と し, 8 \sim 9$ 日目に 最高品温約 $15^{\circ} \mathrm{C}$ とた後, 約 $12^{\circ} \mathrm{C}$ まで徐々に降温し, 20 日目に上槽した。

\section{4. 分析方法}

酢酸は酵素法または $\mathrm{HPLC}^{6)}$ で，有機酸は HPLC, 香気成分はへッドスペース-GC 法7で定量し た。アルコール分は蒸留後, 振動密度計で, 日本酒度 も振動密度計で測定した。その他の分析は国税庁所定 分析法に従った。菌体の ACS 活性は, 菌体破砕液上澄 を用い, POSTMA ら ${ }^{8)}$ の方法で測定した。菌体破砕液の タンパク質濃度は，バイオラッド社製プロテインアッ セイキットを用い，ウシ血清アルブミンで作成した検 量線を用いて測定した。小仕込み試験による製成酒の 官能評価は, 当室員 10 名をパネルとし， 1：良い〜 5： 悪いの 5 点法で行った。各種抗生物質の変異株に対す る最少生育阻害濃度は, 曲淵ら ${ }^{9}$ の方法に従い, $4 \%$ グ リ七ロールを炭素源とするWickerham の寒天培地を 用いて， $30^{\circ} \mathrm{C} て ゙ の$ 生育の有無で判断した。

\section{結果}

\section{1. セルレニン耐性株からの酶酸低生産性変異株の 分離}

得られたセルレニン耐性株 80 株を用いて, 液体静置 培養を行ったところ， $\mathrm{OD}_{660}$ の值が協会 7 号と大差な く, 培饗液上澄の酢酸濃度が協会 7 号より低い株が 14 株得られた。これらの株を用いて小仕込み試験を行っ たところ，協会 7 号の製成酒の酢酸濃度が $442.2 \mathrm{mg} /$ $\ell$ であったのに対し， 7 株の製成酒は $300 \mathrm{mg} / \ell$ 以下， そのうち 4 株は $200 \mathrm{mg} / \ell$ 以下と低い值を示した (Table 2)。Table 2 に示さなかった 3 株の製成酒は, 
後藤 (山本) ・劉・石川・岡崎：セルレニン耐性による酢酸低生産性清酒酵母の分離

Table 2 Analysis of sake fermented by low acetic acid-producing strains.

\begin{tabular}{lrrrrrrrrc}
\hline \hline Strain & Acteta & $\begin{array}{c}\text { Pyruvate } \\
\text { No. }\end{array}$ & $\begin{array}{c}\text { Isoamyl } \\
\text { acetate } / \ell\end{array}$ & $\begin{array}{c}\text { Ethyl } \\
\text { caproate } \\
\mathrm{mg} / \ell\end{array}$ & $\begin{array}{c}\text { Alcohol } / \ell \\
\%\end{array}$ & $\begin{array}{c}\text { Sake- } \\
\text { meter }\end{array}$ & $\begin{array}{c}\text { Titerable } \\
\text { acidity } \\
\mathrm{m} \ell\end{array}$ & $\begin{array}{c}\text { Sensory } \\
\text { evaluation }\end{array}$ & $\begin{array}{c}\text { Overall } \\
\text { result }\end{array}$ \\
\hline K -7 & 442.2 & 19.2 & 2.89 & 1.80 & 18.9 & 4.1 & 3.0 & 3.6 & $/$ \\
No.86 & 120.7 & 18.5 & 3.87 & 6.38 & 19.5 & 1.7 & 2.1 & $\mathrm{NT}$ & $/$ \\
\hline K 7-88 & 381.6 & 17.2 & 1.84 & 5.22 & 19.2 & 7.0 & 2.6 & 3.1 & $\times$ \\
K 7-99 & 703.3 & 17.0 & $\mathrm{NT}$ & $\mathrm{NT}$ & 18.7 & -2.2 & 3.5 & 3.5 & $\times$ \\
K 7-100 & 253.5 & 21.2 & 1.92 & 0.82 & 18.7 & 1.7 & 3.0 & 3.2 & $\triangle$ \\
K 7-104 & 440.9 & 16.7 & 1.98 & 1.19 & 19.9 & 7.8 & 3.3 & 3.5 & $\times$ \\
K 7-105 & 175.2 & 192.8 & 1.75 & 1.12 & 19.4 & 8.6 & 3.2 & 3.9 & $\times$ \\
K 7-112 & 288.2 & 15.6 & 1.74 & 0.87 & 20.1 & 9.3 & 3.0 & 3.2 & $\triangle$ \\
K 7-117 & 335.7 & 23.4 & 1.77 & 1.01 & 17.1 & -17.2 & 3.0 & 3.4 & $\times$ \\
K 7-133 & 4.8 & 229.7 & 5.09 & 2.90 & 18.4 & 11.3 & 2.8 & 3.0 & $\times$ \\
K 7-136 & 14.3 & 25.8 & 4.64 & 10.74 & 18.1 & -5.6 & 2.2 & 1.7 & $\bigcirc$ \\
K 7-157 & 299.2 & 32.7 & 1.47 & 5.13 & 19.3 & 9.7 & 3.0 & 2.8 & $\triangle$ \\
K 7-163 & 176.7 & 17.0 & 2.61 & 8.41 & 19.4 & 4.8 & 2.6 & 2.3 & $\bigcirc$ \\
\hline
\end{tabular}

NT : not tested.

Sensory evaluation: 1 , good $\sim 5$, bad.

Overall result : $\bigcirc$, good : $\triangle$, moderate $\times$, bad

協会 7 号と同程度かそれ以上の酢酸濃度を示した。酢 酸濃度が $200 \mathrm{mg} / \ell$ 以下であった 4 株のうち, K 7-105 とK 7-133の 2 株の製成酒は高いピルビン酸濃度を 示し, 醪期間を延長してもこの傾向は変わらなかった。 また, Table 2 に示す 11 株のうち，4 株はカプロン酸 エチル高生産性を示した。

官能評価の結果，K 7-136 と K 7-163 が高い評価を 得た。このうち, K 7-136 は, 醪末期の発酵が緩慢で進 まなくなる傾向にあったため, K 7-163 を用いてパイ ロットスケールの試験醸造を行った。

\section{2. 試験䁔造結果}

協会 7号と K 7-163 は，ほほ同様の品温およびアル コール分の経過を示した。一方，整ろ液の酢酸濃度は， 協会 7 号が留め後 7 日目までに大きく上昇したのに対 し, K 7-163では終始低い值で推移し(Fig. 1), 製成酒 (純米) の酢酸濃度は, 協会 7 号が $136.6 \mathrm{mg} / \ell$ に対

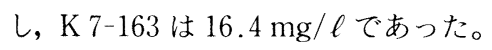

K 7-163 の製成酒は，協会 7 号の製成酒に比較して， アルコール分, 日本酒度ともやや低い値を示し, アミ ノ酸度は高い值を示した（Table 3)。上槽前の酵母の メチレンブルー染色率は, 協会 7 号が $4.3 \%$ に対し, K 7-163は 9.5\%とやや高い値を示した。

また, K 7-163 の製成酒は,リンゴ酸及びカプロン酸 エチル濃度が高い值を示した。この他の分析項目では, 大きな差異は認められなかった。

\section{3. 高浸透圧条件での酶酸生成}

酵母は, 高浸透圧条件では, 菌体内浸透圧を高める ため,グリセロールを高生産することが知られてい る ${ }^{10)}$ 。グリセロール生産では NADH が消費されるた め, 同時に $\mathrm{NAD}^{+}$を消費して $\mathrm{NADH}$ を生成するアセ トアルデヒドや $2-$ オソグルタン酸の酸化反応が促 進され, 酢酸やコハク酸の生成が促進されると考えら れている ${ }^{11}$ 。そこで, 今回得られた酶酸低生産性変異株 4 株の高浸透圧条件での酢酸生産性を調べるため, グ ルコース濃度を $2 \%$ とした合成培地を対照とし, 対照

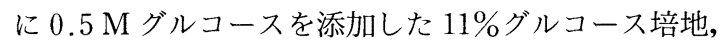

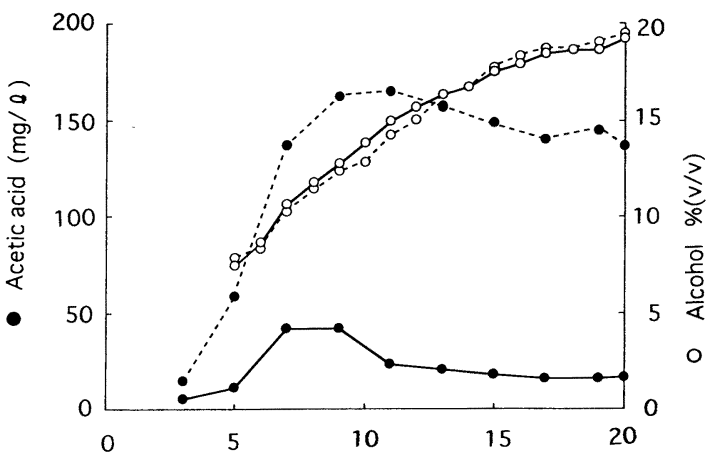

Fig. 1 Change of alcohol and acetic acid concentrations during a pilot scale sake fermentation test using K 7 (broken line) and its mutant, K 7-163 (unbroken line). 
Table 3 Analysis of sake made on a polot scale.

\begin{tabular}{|c|c|c|c|}
\hline Yeast strain & & K 7 & K 7-163 \\
\hline \multirow{4}{*}{$\begin{array}{l}\text { General } \\
\text { analysis }\end{array}$} & Alcohol (\%) & 19.5 & 19.2 \\
\hline & Sake meter & 2.02 & -1.59 \\
\hline & Titerable acidity $(\mathrm{m} \ell)$ & 1.9 & 1.9 \\
\hline & Formol nitrogen $(\mathrm{m} \ell)$ & 1.6 & 1.9 \\
\hline \multirow{5}{*}{$\begin{array}{l}\text { Organic } \\
\text { acid } \\
(\mathrm{mg} / \ell)\end{array}$} & Malic acid & 262.8 & 387.4 \\
\hline & Succinic acid & 434.0 & 403.4 \\
\hline & Lactic acid & 528.6 & 533.9 \\
\hline & Acetic acid & 136.6 & 16.4 \\
\hline & Pyruvic acid & 25.7 & 20.4 \\
\hline \multirow{3}{*}{$\begin{array}{l}\text { Flavour } \\
\text { component } \\
(\mathrm{mg} / \ell)\end{array}$} & $\mathrm{i}-\mathrm{AmOH}$ & 179.1 & 156.3 \\
\hline & $\mathrm{i}-\mathrm{AmOAc}$ & 4.56 & 3.81 \\
\hline & EtOCap & 1.62 & 7.16 \\
\hline
\end{tabular}
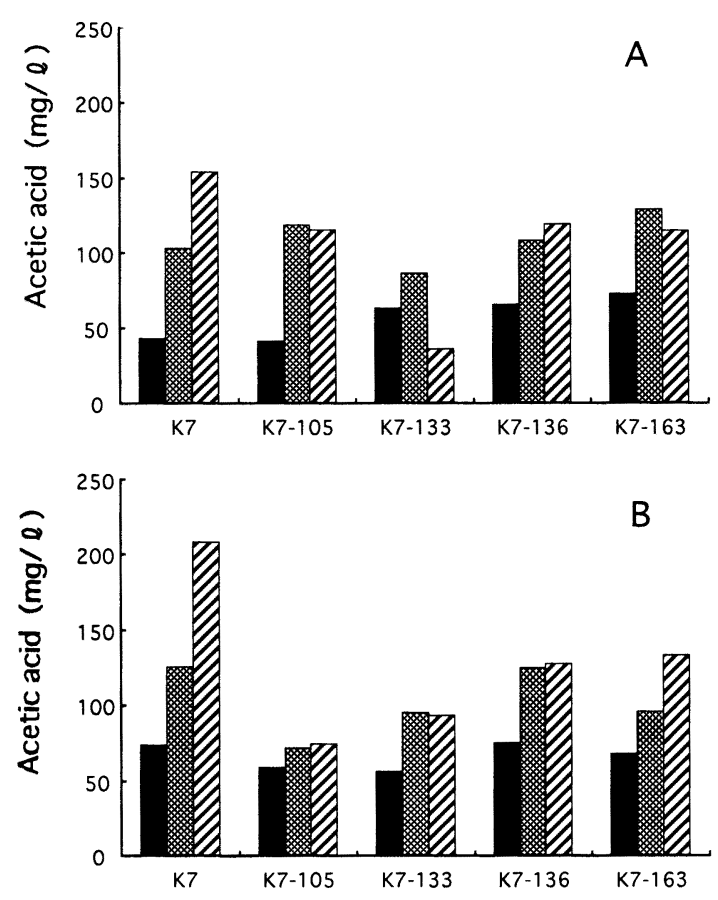

Fig. 2 Acetic acid concentration of the medium after fermentation under anaerobic conditions (A) and semi-aerobic conditions produced using cotton plugs (B). K-7 and its low acetic acidproducing mutants were cultivated in the synthetic medium containing $2 \%$ glucose (closed bar), synthetic medium containing $2 \%$ glucose and $0.5 \mathrm{M}$ sorbitol (shaded bar) or synthetic medium containing $11 \%$ glucose (hatched bar) at $20^{\circ} \mathrm{C}$.

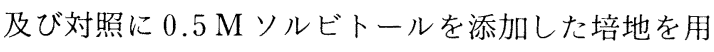
い, 発酵栓を付けた嫌気的状態 (A) と樹脂性綿栓 (シ リコ栓）を付けたやや好気的状態 (B) で, $20^{\circ} \mathrm{C} て ゙$ 静置 培養を行った。なお, 発酵前の $11 \%$ グルコース培地と
$0.5 \mathrm{M}$ ソルビトール添加培地は同じ浸透圧を示す。 アルコール発酵終了後, 協会 7 号は, $2 \%$ グルコース 培地, $0.5 \mathrm{M}$ ソルビトール添加培地, $11 \%$ グルコース 培地の順に培養液の酶酸濃度が高くなった。变異株 4 

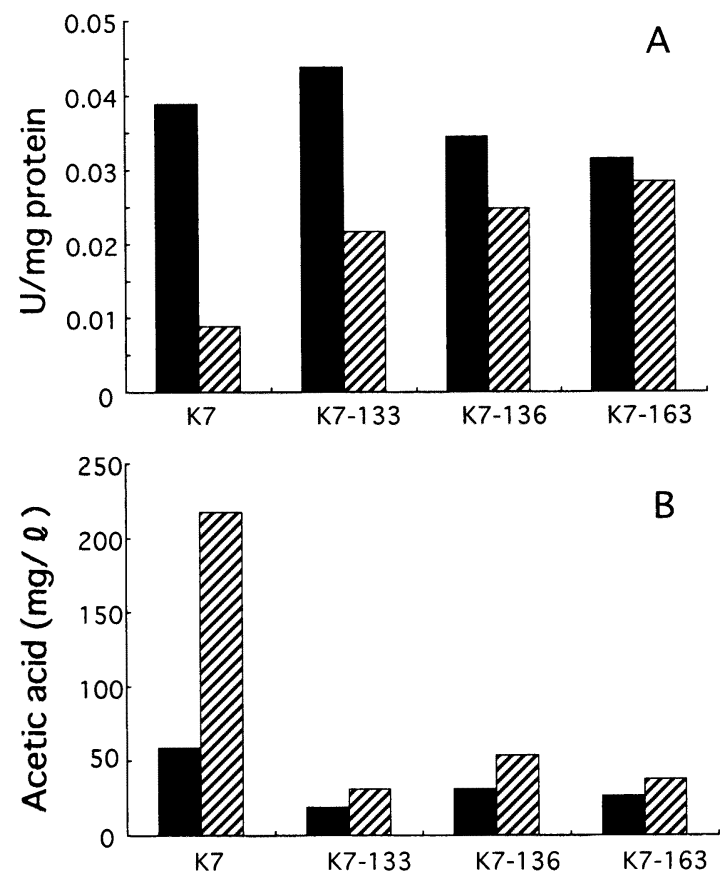

Fig. 3 Acetyl $\mathrm{Co}^{-} \mathrm{A}$ synthetase activities of crude extracts of yeast cells (A) and acetic acid concentrations of the medium (B). K-7 and its low acetic acid-producing mutants were cultivated in synthetic medium containing $10 \%$ glucose at $20^{\circ} \mathrm{C}$ to an $\mathrm{OD}_{660}$ of $0.5-1.0$ (closed bar) or greater than 2.0 (hatched bar).

Table 4 Minimum inhibitory concentration $(\mathrm{mg} / \ell)$ of various antibiotics for the low acetic acid producing mutants.

\begin{tabular}{lcccc}
\hline \hline & Cycloheximide & Oligomycin & Clotrimazole & Cerulenin \\
\hline K 7 & 0.10 .2 & $0.5-1.0$ & $0.5-1.0$ & $0.2-0.5$ \\
K 7 105 & $5<$ & $1.0-2.0$ & $10.0-20.0$ & $1.0-2.0$ \\
K 7 1333 & $2.0-5.0$ & $1.0-2.0$ & $5.0-10.0$ & $5.0<$ \\
K 7 136 & $2.0-5.0$ & $2.0-5.0$ & $10.0-20.0$ & $5.0<$ \\
K 7 163 & $0.1-0.2$ & $0.5-1.0$ & $0.5-1.0$ & $2.0-5.0$ \\
\hline
\end{tabular}

Aerobically precultured cells were spotted onto agar plates of Wickerham's media containing $4 \%$ glycerol as a carbon souce and an antibiotic, and incubated at $30^{\circ} \mathrm{C}$.

株の $2 \%$ グルコース培地での酢酸生産性は協会 7 号と 大差なく, $0.5 \mathrm{M}$ ソルビトール添加培地においても協 会 7 号と同様, $2 \%$ ル゙ルース培地よりも高い酢酸濃 度を示した。従って, 変異株は浸透圧の影響を受けな くなっているのではないと考えられる。一方, 変異株 の $11 \%$ グルコース培地の酢酸濃度は, 親株よりも低
く, $0.5 \mathrm{M}$ ソルビトール添加培地と同程度であった。 また，発酵栓を付けない若干好気的な条件での酢酸の 生産性も親株より低かった（Fig. 2)。なお, 発酵終了 後の酶酸濃度とコハク酸濃度との間に, 一定の傾向は 認められなかった。 


\section{ACS 活性}

協会 7 号及び変異株のうち 3 株を合成培地で $20^{\circ} \mathrm{C}$, 静置培養し, $\mathrm{OD}_{660}$ が $0.5 \sim 1.0$ を示す増殖初期と, 2.0 以上を示す増殖後期に菌体をサンプリングし，菌体抽 出液の ACS 活性を測定した。その結果 (Fig. 3), 協会 7 号では増殖後期に ACS 活性が大きく低下するのに 対し, 変異株の 3 株では増殖後期も ACS 活性が比較 的高く保たれていた。また，同時に採取した培養液上 澄の酢酸濃度も, 協会 7 号では增殖後期に酶酸濃度が 高くなるのに対して，変異株では増殖後期も酶酸濃度 があまり上昇しなかった。

従って, 変異株では ACS 活性が増殖後期まで高く 保たれていることが，酶酸生成の低い原因の少なくと も1つであると考えられた。

\section{5. 多剂耐性}

酵母においても複数の作用機作の異なる抗生物質に 対して耐性を示す多剤而性変異が知られている。そこ で，酢酸低生産性変異株に対する，シクロへキシミド (タンパク質合成阻害剤)，オリゴマイシン（酸化的リ ン酸化阻害剤),クロトリマゾール (エルゴステロール 合成阻害剤), 及びセルレニンの最少生育阻害濃度を調 べた。その結果（Table 4), K 7-163 は，セルレニン以 外の抗生物質に対しては協会 7 号と同じ濃度で生育阻 害を受けたが，他の 3 株は供試した 4 種類の抗生物質 に対して協会 7 号よりも高い耐性を示し，多剤耐性を 獲得していることが示された。

\section{考察}

清酒酵母の抗生物質耐性変異株から，香気成分や有 機酸生成能,アルコール発酵能などの醸造特性の変異 した株が種々分離されている ${ }^{9,12 \sim 15)}$ 。このうち, セルレ ニン耐性によるカプロン酸エチル高生産性変異は, 脂 肪酸合成酵素をコードする FAS 2 の変異が原因であ ることが報告されている ${ }^{13)}$ 。今回得られた酢酸低生産 性を示すセルレニン耐性株 4 株のうち 2 株はFAS 2 変異によると考えられるカプロン酸エチル高生産性を 示した。しかし, FAS 2 変異が酶酸の生産性に変化を 与えないことは，上東ら ${ }^{16)}$ の報告に示されており，酢 酸低生産性は併せ持つ他の変異によると考えられる。 今回得られた変異株 3 株は増殖後期も高い ACS 活性 を示し，これが酢酸低生産性の原因の少なくとも一つ であると推察された。今後, 菌体内アセチル $\mathrm{Co}^{-} \mathrm{A}$ 濃
度や各種条件下での ACS 活性の測定等を行い，酢酸 低生産性となる要因の検討を行いたい。

一方，酶酸低生産株 4 株のうち 3 株は多剤耐性を示 し，多剤耐性を示さなかった K 7-163 もFAS 2 変異 によると考えられるカプロン酸エチル高生産性を示し た。従って, セルレニン耐性株の中から比較的高頻度 で酶酸低生産性株を分離することができたが，七ルレ ニン耐性と酶酸低生産性がリンクしているか否かも今 後の検討課題である。

\section{要 約}

協会 7 号酵母のセルレニン耐性株 80 株のうち 14 株 が液体培養で，さらに 4 株が清酒の小仕込み試験で酿 酸低生産性を示し，1株はパイロットスケールの清酒 試験醸造においても低い酢酸生産性を確認した。これ ら 4 株は，0.5 M ソルビトールを添加して高浸透圧と した液体培地では, 親株と同様, 対照の $2 \%$ グルコース 培地よりも酢酸生成が促進されたが，11\%グルコース 培地では親株よりも低い酢酸生成を示した。また，こ のうち 3 株は増殖後期も高い ACS 活性を示し，これ が酢酸低生産性に関与しているものと推察された。し かし，これら 4 株は多剤耐性またはFAS 2 変異によ ると考えられるカプロン酸エチル高生産性を示し，セ ルレニン耐性と酢酸低生産性がリンクしているかどう かは今後検討を要する。

終わりに, 本研究に対し, 貴重なディスカッション 及びご協力を戴いた, 白鶴酒造研究開発室, 赤松誠司 氏，並びに当所福田央主任研究員に感謝します。

\section{文献}

1）永井英雄, 近藤恭一, 三島秀夫, 竹村成三：醗工, 70, 361-369 (1992)

2）蓼沼誠，武藤浩，古市明紀，設楽和平：醸試報, 135, 64-73 (1963)

3) Y.Shimazu and M. Watanabe: J. Ferment. Technol., 59, 27-32 (1981)

4) F. RADLER : Wine microbiology and biotechnology. G. H. FleEt (ed.), P. 169-172. Harwood Academic Publishers, Chur (1993)

5) C. Verduyn, E. Postma, W. A. Scheffers and J. P. van Dijken: J. Gen. Microbiol., 136, 395-403 (1990)

6）木崎康造, 福田央, 高橋康次郎：醸協，93（2）, 


$$
148-152 \text { (1998) }
$$

7）石川雄章, 荒巻功, 後藤奈美, 福田央, 高橋康次 郎：醸研報, 171, 1-11（1999）

8) E. Postma, C. Verduyn, W. A. Scheffeers and J. P. van DiJken: Appl. Environ. Microbiol., 55, 468-477 (1989)

9）曲淵哲朗, 森川貴子, 岩瀬利徳, 福田秀雄, 佐々木 清祐：醇苦協, 92（2）, 143-150（1997）

10) S. Hohmann : Yeast stress response, S. HoH MANN and W. H. MAGER (eds.), p. 101-145, Springer, New York (1997)

11) F. Remiz, J. L. Roustan, J. M. Sablayrolles,
P. BARre and S. DeQUin : Appl. Environ. Microbiol., 65, 143-149 (1999)

12) E. Ichikawa, N. Hosokawa, Y. Hata, Y. Abe, K. Suginami and S. Imayasu: Agric. Biol. Chem., 55, 2153-2154 (1991)

13）市川英治：醇協, 88 （2），101-105（1993）

14）溝口弘子, 渡辺睦, 西村顕, 近藤恭一：生物工学, 76, 194-199 (1998)

15）溝口 (藤城) 弘子, 渡辺睦, 永井英雄, 西村顕, 近藤 恭一：醸協, 93 (8), 665-670（1998）

16）上東治彦, 中川悦子, 森山洋憲, 永田信治, 味園春 雄：醸協, 94（1）,63-71（1999） 